\title{
Model uncertainty and Bayesian estimation of growth parameters of Yellowtail Snapper (Ocyurus chrysurusu) from Veracruz, Mexico
} Incertidumbre de modelación y estimación Bayesiana de los parámetros de crecimiento de la rubia (Ocyurus chrysurus) de
Veracruz, México

\author{
Jesús Jurado-Molina ${ }^{1}$ Osvaldo Gutiérrez-Benítez² and Alejandro Roldan-Heredia² \\ ${ }^{1}$ Departamento de El Hombre y su Ambiente, División de Ciencias Biológicas y de la Salud, Universidad Autónoma Metropolitana, Unidad Xochimilco. Calzada del Hueso \\ 1100, Col. Villa Quietud, Coyoacán, Ciudad de México, 04960. México \\ ${ }^{2}$ Posgrado de Ecología y Pesquerías, Universidad Veracruzana. Calle Independencia 30 (antes 38), Piso 1 y 2 Colonia Centro, Boca del Río, Veracruz, 94290. México \\ e-mail: jjurado@uw.edu
}

Recibido: 22 de febrero de 2017. Aceptado: 09 de junio de 2018.

Jurado-Molina J., 0. Gutiérrez-Benítez and A. Roldan-Heredia. 2018. Model uncertainty and Bayesian estimation of growth parameters of Yellowtail Snapper (Ocyurus chrysurus) from Veracruz, Mexico. Hidrobiológica 28 (1): 191-199. D0I: 10.24275/uam/izt/dcbs/hidro/2018v28n2/Jurado

\begin{abstract}
Background. Most growth analyses of Yellowtail Snapper neglect consideration of model and parameter uncertainty. Goals. In this paper, we explore model uncertainty using three models (von Bertalanffy, logistic, and Gompertz) as well as the Akaike criterion for model selection. We also estimate growth parameters and its uncertainty using the maximum likelihood estimation approach (under different assumptions of error variance) and Bayesian methods. Methods. Models were fitted to length-at-age data from organisms caught in Antón Lizardo, Veracruz. Regarding the Bayesian methods, a prior distribution for the asymptotic length was built based on data gathered from literature. We used Monte Carlo Markov Chains (MCMC) methods to fit the logistic model. Results. The Akaike criterion results suggest that the logistic model provided the best fit for the observed data (lowest AIC $=31.4)$. Parameter estimates included asymptotic length $\left(L_{\infty}=64.9\right.$ $\pm 5.43)$, growth rate $(K=0.49 \pm 0.07)$, and age at the curve inflection point $(I=3.28 \pm 0.42)$. Regarding the Bayesian analysis, MCMC simulations suggest that the most probable value for the asymptotic length was $64.3 \mathrm{~cm}$ with an interval of $95 \%$ probability $(58.7,70.1)$. The most probable value for the growth rate was 0.48 with an interval of $95 \%$ probability $(0.42,0.55)$. Last, the most probable value for the age at the curve inflection point was 1.7 years with a range of $95 \%$ probability $(1.31,2.16)$. Conclusions. The maximum likelihood estimation (MLE) and the Bayesian framework should be considered basic statistical techniques in the evaluation of individual growth of the species of interest, as they provide a robust analysis of available information of the species and the opportunity to incorporate such analysis to sustainable management practices.
\end{abstract}

Keywords: Bayesian estimation, growth, likelihood, Ocyurus chrysurus, Veracruz

\section{RESUMEN}

Antecedentes. La mayoría de los análisis de crecimiento hechos para rubia no toman en cuenta la incertidumbre del modelo, ni de los parámetros. Objetivos. Explorar la incertidumbre de los modelos usando tres modelos distintos (von Bertalanffy, logístico y Gompertz) y el criterio de Akaike. También estimar los parámetros de crecimiento y su incertidumbre con métodos de máxima verosimilitud (con tres supuestos para la variancia residual) y Bayesianos. Métodos. Los modelos se ajustaron a datos de longitud por edad de organismos capturados en Antón Lizardo, Veracruz. En cuanto a los métodos Bayesianos, se construyó una distribución a priori para la longitud asintótica basada en información de la literatura. Se usó la metodología Cadenas de Markov de Monte Carlo (CMMC) para ajustar el modelo logístico. Resultados. Los resultados del criterio de Akaike sugirieron que el modelo logístico fue el que mejor se ajustó a los datos observados. Las estimaciones de Ios parámetros fueron: Longitud asintótica $\left(L_{\infty}=64.9 \pm 5.43\right)$, tasa de crecimiento $(K=0.49 \pm 0.07)$ y la edad para el punto de inflexión ( $I=3.28 \pm 0.42$ ). En cuanto al análisis Bayesiano, las simulaciones MCMC sugirieron que el valor más probable para la longitud asintótica fue $64.3 \mathrm{~cm}$ con intervalo de $95 \%$ de probabilidad de $(58.7,70.1)$. El valor más probable para la tasa de crecimiento fue 0.48 con intervalo de probabilidad de $95 \%$ de $(0.42,0.55)$. Finalmente, el valor más probable para la edad en el punto de inflexión fue 1.7 años con intervalo de $95 \%$ de probabilidad de $(1.31,2.16)$. Conclusiones. Los métodos de máxima verosimilitud y Bayesianos deben ser considerados como herramientas estadísticas básicas para la evaluación del crecimiento individual, debido a que proveen un análisis robusto de la información disponible de la especie y la oportunidad de incorporar dichos análisis a acciones de manejo para la explotación sustentable del recurso.

Palabras clave: crecimiento, estimación Bayesiana, Ocyurus chrysurus, Veracruz, verosimilitud 


\section{INTRODUCTION}

Yellowtail Snapper (Ocyurus chrysurus (Bloch, 1791) is found in tropical and subtropical waters from the western Atlantic Ocean, from Massachusetts USA to Brazil, including Bermuda, Gulf of Mexico, Antilles, Bahamas, South Florida and the Caribbean (Allen, 1985). Larvae are pelagic with broad dispersion (Riley et al., 1995); juveniles are mainly associated to Turtle Grass Thalassia testudinium Banks ex König (Borton \& Williams 1986), while adults form schools around coral reefs (Manooch \& Drennon, 1987). Commercial and recreational fisheries developed around the coral reefs in South Florida (SEDAR, 2003; Mc Clellan \& Cummings, 1998). According to Allen (1985) and Heemstra and Randall (1993), in the southeast Gulf of Mexico, Yellowtail Snapper is caught together with fourteen species of grouper (Epinephelus sp.) and fourteen species of snapper (Lutjanus sp.). In particular, in Veracruz, Mexico, the artisanal fleet from Antón Lizardo catches Yellowtail Snapper all year around. The main fishing ground is located within the protected area "Parque Nacional Sistema Arrecifal Veracruzano" (PNSAV) (Fig. 1). The most common fishing gear used in the fishery is the hook; however, long line, troll, gillnet, harpoon, and creek are also used (Jiménez-Badillo et al., 2006). Similar to Florida, this is a multispecies fishery and Yellowtail Snapper landings represent $5 \%$ of the total catch from thirty-three species caught. Yellowtail Snapper catch ranks sixth in abundance in the zone (Jiménez-Badillo \& Castro-Gaspar, 2008). This fishery is regulated through fishing permits issued by the Comisión Nacional de la Pesca (CONAPESCA), with scientific advice from the Instituto Nacional de la Pesca (INAPESCA). Recently, fishery managers recommended reducing fishing and increasing research in order to increase the available information aimed at establishing adequate reference points and improving regulations to manage this multispecies fishery (INAPESCA, 2012). In terms of research, there is a considerable amount of information on Yellowtail Snapper growth, which has been determined by studying hard structures such as otoliths, scales, etc. (Johnson, 1983; Manooch \& Drennon, 1987; Carrillo de Albornoz \& Ramiro, 1988; Carrillo de Albornoz, C. 1999. García et al., 2003; Leite Jr. et al., 2005; Gutiérrez-Benítez, 2012), by length distributions (AguirreGarcía et al., 2004; Mattos \& Maynou, 2009), and by a mix of these two methods (Mexicano-Cíntora, 1999; Dennis, 1991). A review of the literature suggests that most researchers assume that the von Bertalanffy equation describes growth by defaut, and they rarely provide estimation of growth-parameter uncertainty (Torres \& Chavez, 1987;) We note that an adequate estimation of growth parameters provides important information for the analysis of how fisheries are affecting species (Ehrhardt, 1981), and for establishing fishery regulations and reference points to assure the sustainable exploitation of marine resources. In this paper, we explore model uncertainty for Yellowtail Snapper growth by comparing and fitting three growth models (von Bertalanffy, Logistic, and Gompertz) to length-at-age data using a maximum likelihood estimation (MLE) approach. We also estimate growth parameters and their uncertainty by MLE (using three assumptions on error variance) and Bayesian approaches. We believe this methodology provides both a robust analysis for assessing the growth of Yellowtail Snapper and complementary information for the management of this resource.

\section{MATERIAL AND METHODS}

Length-at-age data determination for Yellowtail Snapper in Veracruz is described in detail in Gutiérrez-Benítez (2012). A total of 188 individuals were collected at the Antón Lizardo landing site. Average length-at-age, sample size by age class (Table 1), and raw data (Figure 2a) are shown below. In this article, we fit length-at-age data to three growth models, the first was the von Bertalanffy model (von Bertalanffy, 1938):

$$
L(t)=L_{\infty}\left(1-e^{-K\left(t-t_{0}\right)}\right)+\varepsilon_{i}
$$

where $L_{\infty}$ is the asymptotic length, $K$ is the growth rate, $t_{0}$ is the age for length equals zero, and $\varepsilon_{i}$ is an independent normal randomly distributed error $\left(\mathrm{N}\left(0, \sigma^{2}\right)\right)$. We also used the logistic model (Ricker, 1975) given by the following equation:

$$
L(t)=\frac{L_{\infty}}{1+e^{-K(t-I)}}+\varepsilon
$$

where $I$ is the age corresponding to the inflection point in the growth curve. The third model was the Gompertz model (Gompertz, 1825) defined by:

$$
L(t)=L_{\infty} e^{-(1 / K) e^{-K(t-I)}}+\varepsilon
$$

We estimated model parameters from equations (1-3) and their uncertainties using the maximum likelihood estimation method (Kimura, 1980); in particular, we used the negative logarithm of the likelihood as the objective function, assuming a normally distributed observation error. According to Kimura (1980), under different assumptions on error variance, four different methods of estimation are appropriate. When these assumptions are met, each method provides maximum likelihood estimations under the likelihood model. In the first option, all individual measurements have constant variance:

$$
L L=\frac{n \ln \left(2 \pi \sigma^{2}\right)}{2}+\frac{\sum_{i=1}^{N} \sum_{j=1}^{n_{i}}\left(l_{i, j}^{\text {obs }}-l_{i, j}^{e s t}\right)^{2}}{2 \sigma^{2}}
$$

where $N$ is the number of age classes, $n$ is the total number of data, $i$ is the age class, $n_{i}$ is the sample size of age class $i, j$ represents an individual's length in age class $i$, I represents length-at-age, and $\sigma$ is the standard error. The second option assumes all average length-atage values have a constant error variance:

$$
L L=\frac{n \ln \left(2 \pi \sigma^{2}\right)}{2}+\frac{\sum_{i=1}^{n}\left(\bar{l}_{i}^{\text {obs }}-\bar{l}_{i}^{e s t}\right)^{2}}{2 \sigma^{2}}
$$

The third option is a variation of the first option (Equation 4), where it is assumed that all average length-at-age values have a constant variance and sample size $n_{i}$ is used as a weighting factor:

$$
L L=\frac{n \ln \left(2 \pi \sigma^{2}\right)}{2}+\frac{\sum_{i=1}^{n} n_{i}\left(\bar{l}_{i}^{\text {obs }}-\bar{l}_{i}^{e s t}\right)^{2}}{2 \sigma^{2}}
$$

There is a fourth option assuming the length-at-age error variance varies with age, but we did not observe this pattern in our data, so we excluded it. In summary, we explored nine options (three models and three assumptions on error variance) for growth parameter estimation. Parameter estimation and uncertainty were carried out using the subroutine "optim" from the statistical package R (R Core Team, 2015).

Model selection for the best fit to observed data was conducted using the Akaike information criterion (1973):

$$
A I C=-2 \ln \left(L_{\max }\right)+2 P
$$

where $L_{\max }$ is maximum likelihood and $P$ is the number of parameters included in the model. 


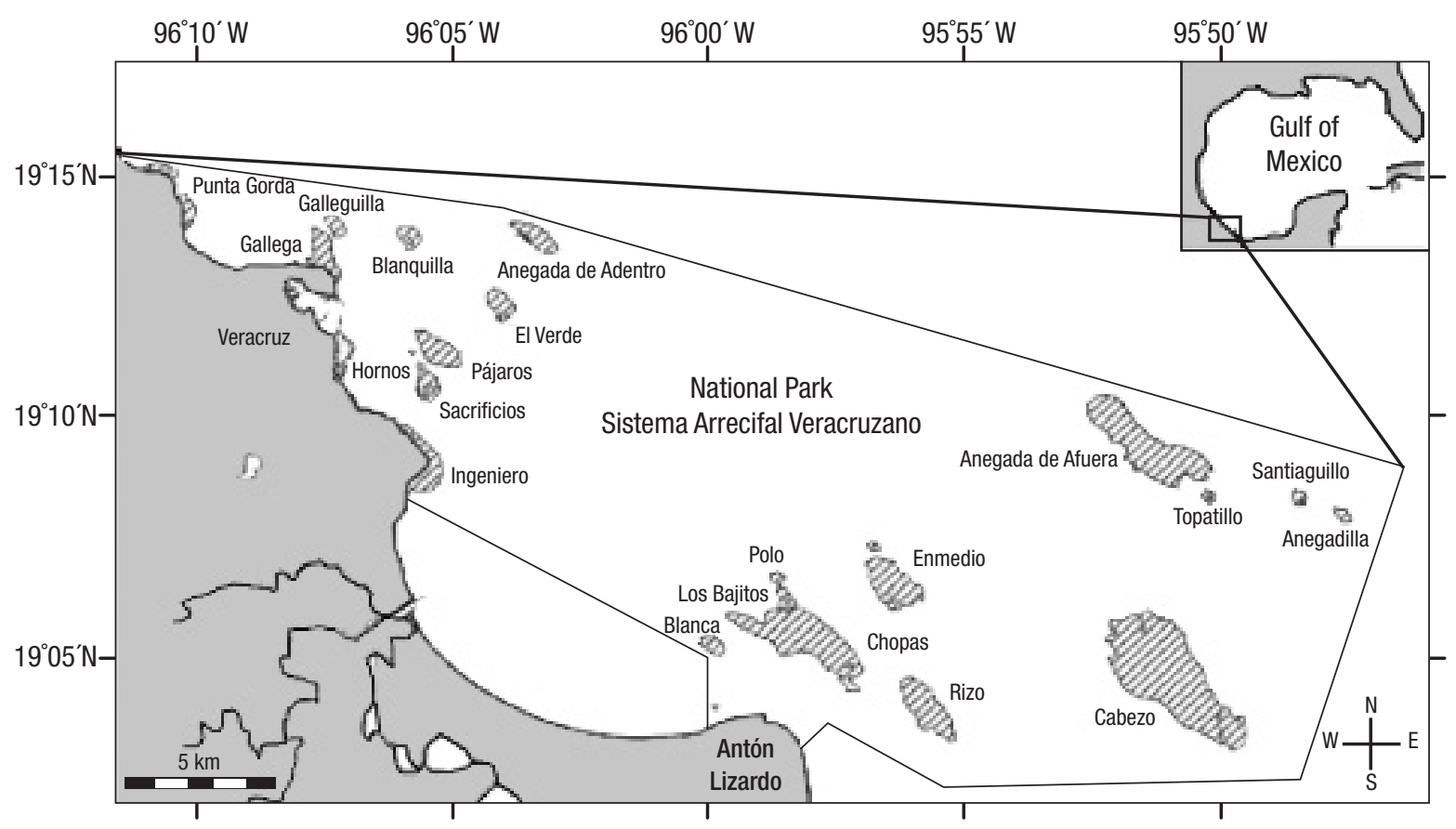

Figure 1. Antón Lizardo area (shaded areas represent reef structures); modified from Okolodkov (2008).

After selecting the best model, a Bayesian estimation (Hilborn \& Mangel, 1997) for the parameters from the logistic growth equation was carried out; this approach allows the incorporation of additional information obtained from previous work into the building of the parameters' prior distributions used in the estimation of their posterior distributions. In this statistical approach, the probability of the hypothesis given the data or posterior distribution $\operatorname{Pr}\left\{H_{i} \mid\right.$ data $\}$ was estimated as:

$$
\operatorname{Pr}\left\{H_{i} \mid \text { data }\right\}=\frac{L\left\{\text { data } \mid H_{i}\right\} \operatorname{Pr} \operatorname{ior}\left\{H_{i}\right\}}{\int_{i} L\left\{\text { data } \mid H_{i}\right\} \operatorname{Pr} \operatorname{ior}\left\{H_{i}\right\}}
$$

where $L$ represents the likelihood of the data-given the hypothesis (parameter value) -and Prior is the prior distribution of each hypothe-

Table 1. Average length-at-age and sample size for each age class of organisms of Yellowtail Snapper Ocyurus chrysurus (Bloch 1791), c0llected at the Antón Lizardo landing site, Veracruz, Mexico.

\begin{tabular}{llc}
\hline Age & Length & Sample size \\
\hline 1 & 15.31 & 7 \\
2 & 25.8 & 6 \\
3 & 27.16 & 51 \\
4 & 38.26 & 76 \\
5 & 45.92 & 37 \\
6 & 52.23 & 8 \\
7 & 54.93 & 3 \\
\hline
\end{tabular}

sis that assumes previous knowledge. We should point out that prior distributions were built based on estimates taken from the literature (Table 2) on Yellowtail Snapper growth. In particular, most of the time, analyses of Yellowtail Snapper growth took the von Bertalanffy model as the default model. Therefore, there was no information on the $\mathrm{K}$ and I parameters used in the logistic model, so we could only build a prior distribution for the asymptotic length that was assumed to be normally distributed with mean $\mu=52.86 \mathrm{~cm}$ and $\sigma=9.17 \mathrm{~cm}$. Due to the lack of prior information, the remaining parameters from the logistic model were assumed to have a uniform distribution.

The posterior distribution of the following parameters was estimated: asymptotic length $L_{\infty}$, growth rate $(K)$, and age corresponding to the inflection point of the growth curve ( $)$. Posterior distributions for the parameters were estimated with Markov Chains Monte Carlo (MCMC). A total of 1,600,000 simulations were made using Excel-Visual Basic, with a burning period of 5000 parameter vectors. We saved the parameters vector every 25 simulations. The recorded information included the posterior probability value (Equation 8), the asymptotic length, the growth rate, and the age for the inflection point. We classified results within the Visual Basic code in thirty bins and built the marginal posterior distributions using the pivot table function in Excel.

\section{RESULTS}

Model fitting results are shown below (Table 3, Fig. 2). As mentioned, we fit three models (Equations 1-3) with three options for variance error (Equations 4-6) for a total of nine scenarios. All models fit the observed data well; however, within each error variance assumption, the logistic model had the lowest Akaike information criterion. In contrast, the von Bertalanffy model consistently had the worst performance (Table 3). 
a)

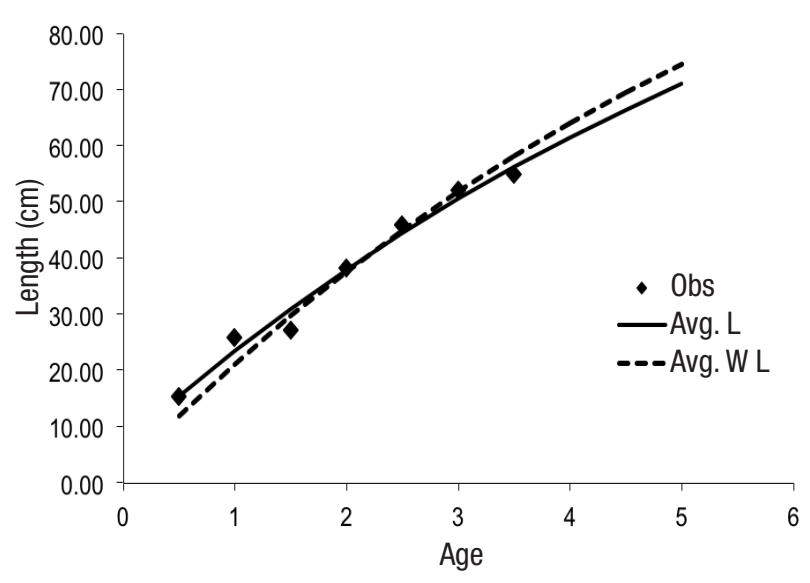

c)

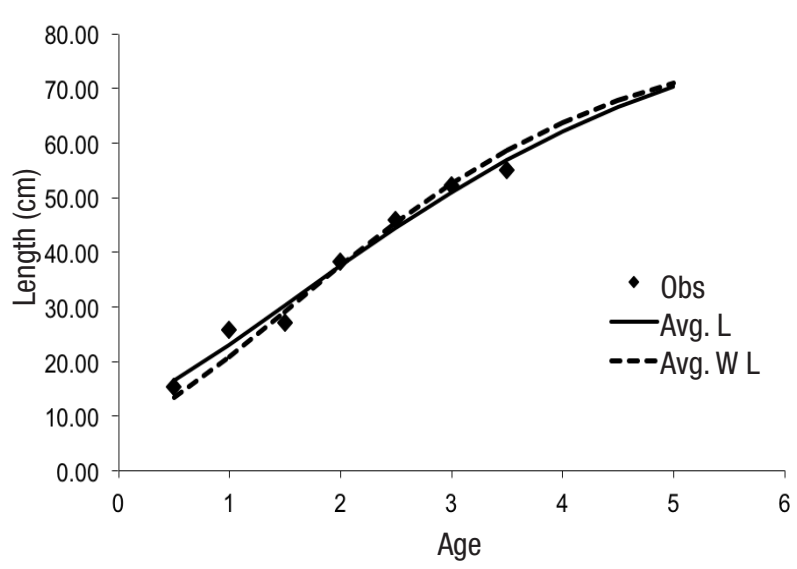

e)

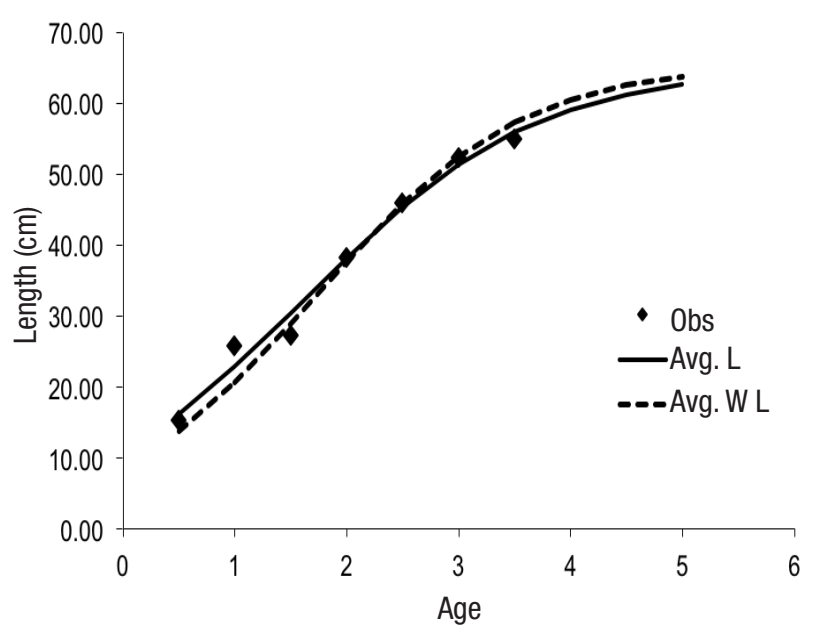

b)

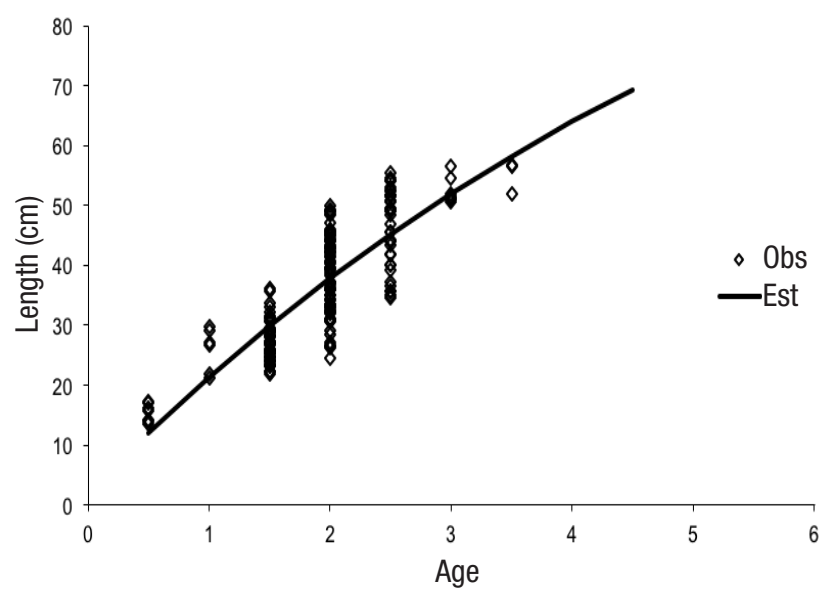

d)

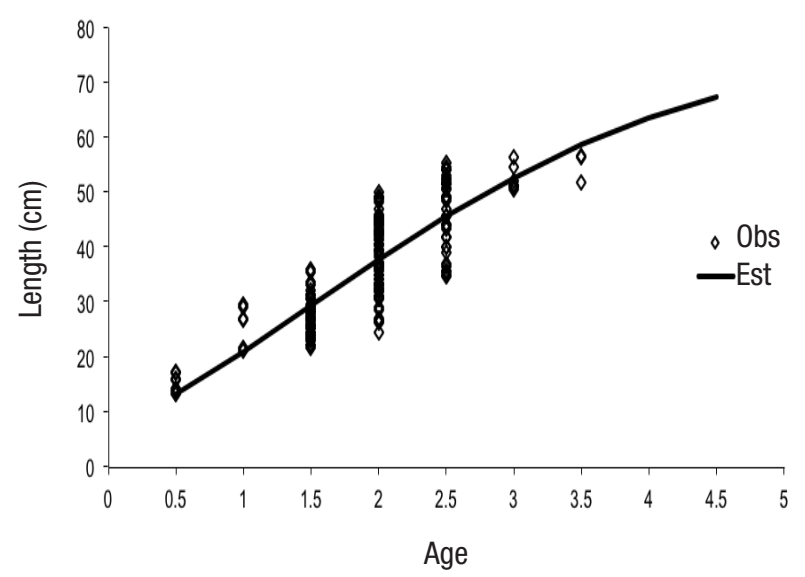

f)

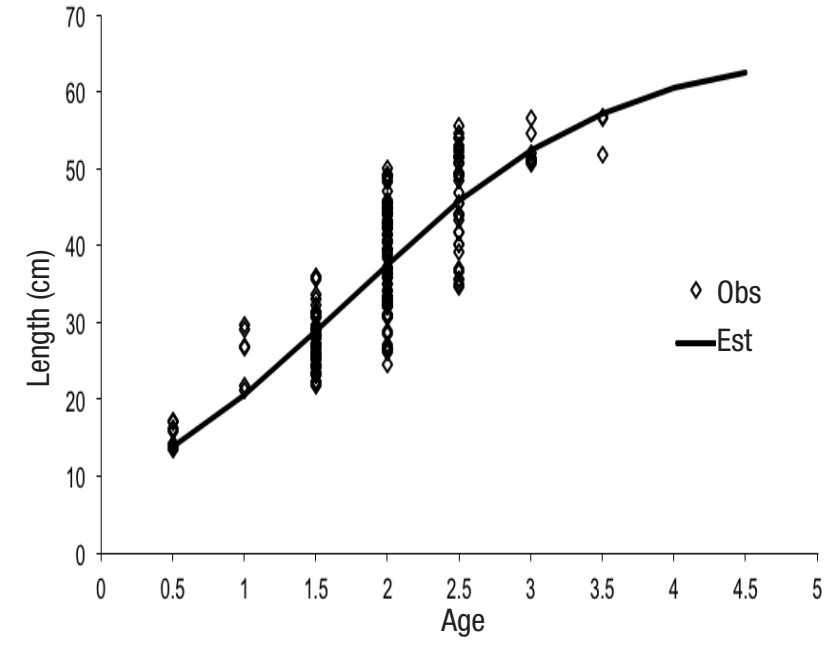

Figures 2a-f. Maximum likelihood estimation (MLE) model fits to observed length-at-age data for Yellowtail Snapper Ocyurus chrysurus (Bloch, 1791). a-b) Von Bertalanffy; c-d) Gompertz; e-f) Logistic; Obs = observed length-at-age data, Avg. L = equation 5 for variance assumption, Avg. W L = equation 6 the variance option. 
The overall lowest AIC (31.41) corresponded to the logistic model using the average length with constant error variance (Equation 5). Therefore, this scenario (Equations 2, 5) was selected as the best fit for the Yellowtail Snapper observed length-at-age. For this scenario, four parameters and their uncertainties were estimated, the asymptotic length $\left(L_{\infty}\right)$ was estimated as $64.9 \pm 5.43 \mathrm{~cm}$, the growth rate was $0.49 \pm$ 0.07 , and the age associated to the curve inflection point ( $($ ) was $3.28 \pm$ 0.42 years. Their corresponding $95 \%$ confidence intervals were $(54.24$, $75.54),(0.35,0.63)$, and $(2.45,4.1)$, respectively. The standard error was $1.77 \pm 0.47$. The highest coefficient of variation corresponded to $\sigma$ (0.27), for a growth rate of 0.14 , for an age associated to the inflexion point of 0.13 , and for an asymptotic length of 0.08 .

We should point out that for the logistic model, confidence intervals overlap for the $L_{\infty}$ estimates obtained from the three options of error variance assumption (Fig. 3); therefore, at the $95 \%$ confidence level, we did not find significant evidence that the estimates are different. Similar results were obtained for the growth rate $(K)$ and the age at the point of inflection $(I)$; however, for the sigma parameter, some confidence intervals did not overlap. The correlation coefficient between the observed and the estimated length at age was 0.99 ( $p$-value $\sim 0)$.

Regarding the Bayesian analysis, results from the MCMC simulations suggest that the logistic model fits the observed data well (Fig.

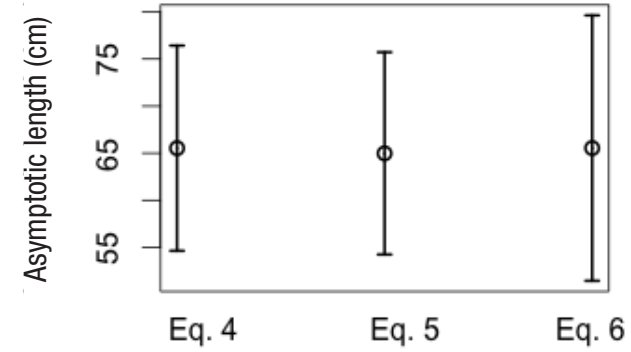

Figure 3. Confidence intervals of the asymptotic length for the logistic model for different error variance assumptions (Eqs. 4-6)

4a). The most probable value for the asymptotic length was $64.3 \mathrm{~cm}$ (mode of the marginal posterior distribution), with a $95 \%$ probability interval of $(58.7,70.1)$. The most probable growth rate was 0.48 with a $95 \%$ probability interval of $(0.42,0.55)$; the most probable value for the age of the inflection point was 1.4 years with a $95 \%$ probability interval of $(1.31,2.16)$. The parameter's marginal posterior distributions are shown below (Fig. 5). Regarding the parameter correlations (Figs $4 \mathrm{~b}-\mathrm{d}$ ), these were high: The correlation between $L_{\infty}$ and $K$ was -0.74 , the correlation between $K$ and $/$ was -0.79 , and for $L_{\infty}$ and $I$, the correlation was 0.87

Table 2. Estimates of asymptotic length for Yellowtail Snapper (Ocyurus chrysurus Bloch, 1791) from previous studies in different regions; $L_{\infty}=$ asymptotic length, Uncertainty = uncertainty estimated.

\begin{tabular}{|c|c|c|}
\hline Author & Region & $L_{\infty}(\mathrm{cm})$ \\
\hline Cantarell (1982) & Yucatan & 53.0 \\
\hline Johnson (1983) & Florida & 45.0 \\
\hline López \& Garduño (1985) & Yucatan & 55.5 \\
\hline Mexicano-Cíntora (1986) & Yucatan & 48.1 \\
\hline Manooch \& Drennon (1987) & Vírgen Islands and Puerto Rico & 50.3 \\
\hline Carrillo de Albornoz \& Ramiro (1988) & SE Cuba & 69.6 \\
\hline Dennis (1991) & Puerto Rico & 53.4 \\
\hline Carrillo de Albornoz (1999) & SO Cuba's Shelf & 62.0 \\
\hline \multirow[t]{9}{*}{ Mexicano-Cíntora (1999) } & Yucatan's north coast (1985) & 50.7 \\
\hline & & 44.9 \\
\hline & & 49.5 \\
\hline & Yucatan's north coast (1986) & 44.0 \\
\hline & & 43.0 \\
\hline & & 42.1 \\
\hline & Yucatan's north coast (1987) & 51.1 \\
\hline & & 47.5 \\
\hline & & 48.7 \\
\hline Araujo et al. (2002) & Brasil's central coast & 56.7 \\
\hline García et al. (2003) & Florida & 60.7 \\
\hline Aguirre-García et al. (2004) & Quintana Roo & 50.0 \\
\hline Allman et al. (2005) & Florida & 41.0 \\
\hline Leite Jr. et al. (2005) & Brasil's east coast & 56.7 \\
\hline Mattos \& Maynou (2009) & NE Brasil & 76.6 \\
\hline Gutiérrez-Benítez (2012) & Veracruz & 68.6 \\
\hline Average Linf & & $52.86 \pm 9.17$ \\
\hline
\end{tabular}




\section{DISCUSSION}

In order to achieve sustainable exploitation of the multispecies fisheries in the Gulf of Mexico, the Carta Nacional Pesquera (National Fishing Chart) (SAGARPA, 2012) suggests that more information on biological and population aspects is needed to accurately determine the exploitable biomass and optimum effort that must be applied in each of the fisheries under criteria of sustainability. In particular, the economy of the Antón Lizardo Community is mostly based on the multi-specific fishery, where Yellowtail Snapper is caught. Therefore, it is important to ensure its sustainable exploitation; more effort is needed to improve the management of this fishery resource. Nearby towns adapted their economy and cultural traits due to the loss of mangrove forest and overexploitation of fishing resources (Aldeco et al., 2015).

A first step towards a sustainable exploitation is to provide important basic information such as species growth. Although several studies have been published on Yellowtail Snapper growth using different methods (Dennis, 1991; Mexicano-Cíntora 1999; Allman et al., 2005; Araújo et al., 2002), they rarely provide a measure of parameter uncertainty. Note that the value of a model-based analysis lies not simply in its abi-

a)

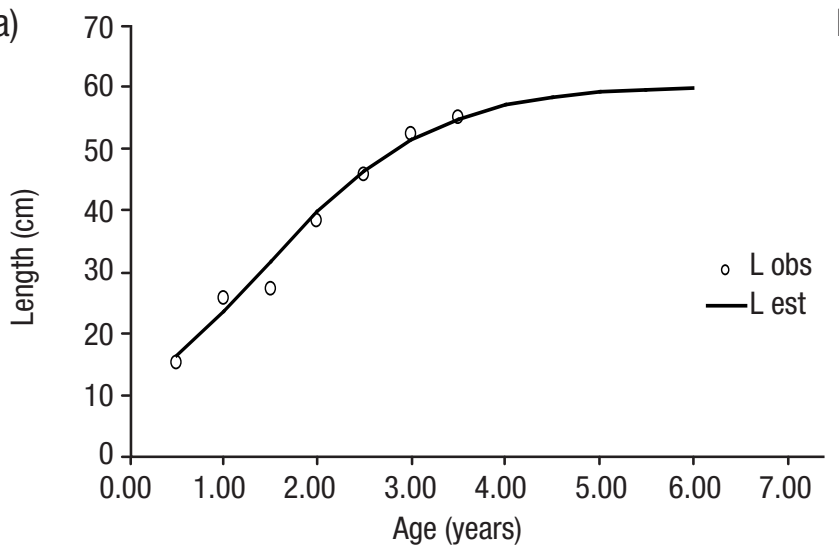

lity to generate a precise point estimate for a specific outcome, but also in the systematic examination and responsible reporting of uncertainty surrounding this outcome (Briggs et al., 2012). Similarly, consideration of uncertainty is essential when management decisions are made, and it is particularly important when applying the precautionary approach to fisheries management (Maunder et al., 2006). Previous studies (Dennis, 1991; Mexicano-Cíntora, 1999; Allman et al., 2005; Araújo et al., 2002; Torres \& Chávez, 1987) assumed by default that the von Bertalanffy model describes Yellowtail Snapper growth adequately; model uncertainty is rarely taken in account; therefore they could be making a modeling error (Punt \& Hilborn, 2001) neglecting the understanding of the dynamic studied. In this paper, we try to improve the methodology used previously by providing two methods: maximum likelihood estimates and Bayesian methods for parameter and uncertainty estimation. We also addressed model uncertainty using three models, three assumptions on error variance, and the Akaike information criterion for model selection.

Our results suggest that the logistic model (Ricker, 1975) shows the best fit for the observed length-at-age data. We should point out that
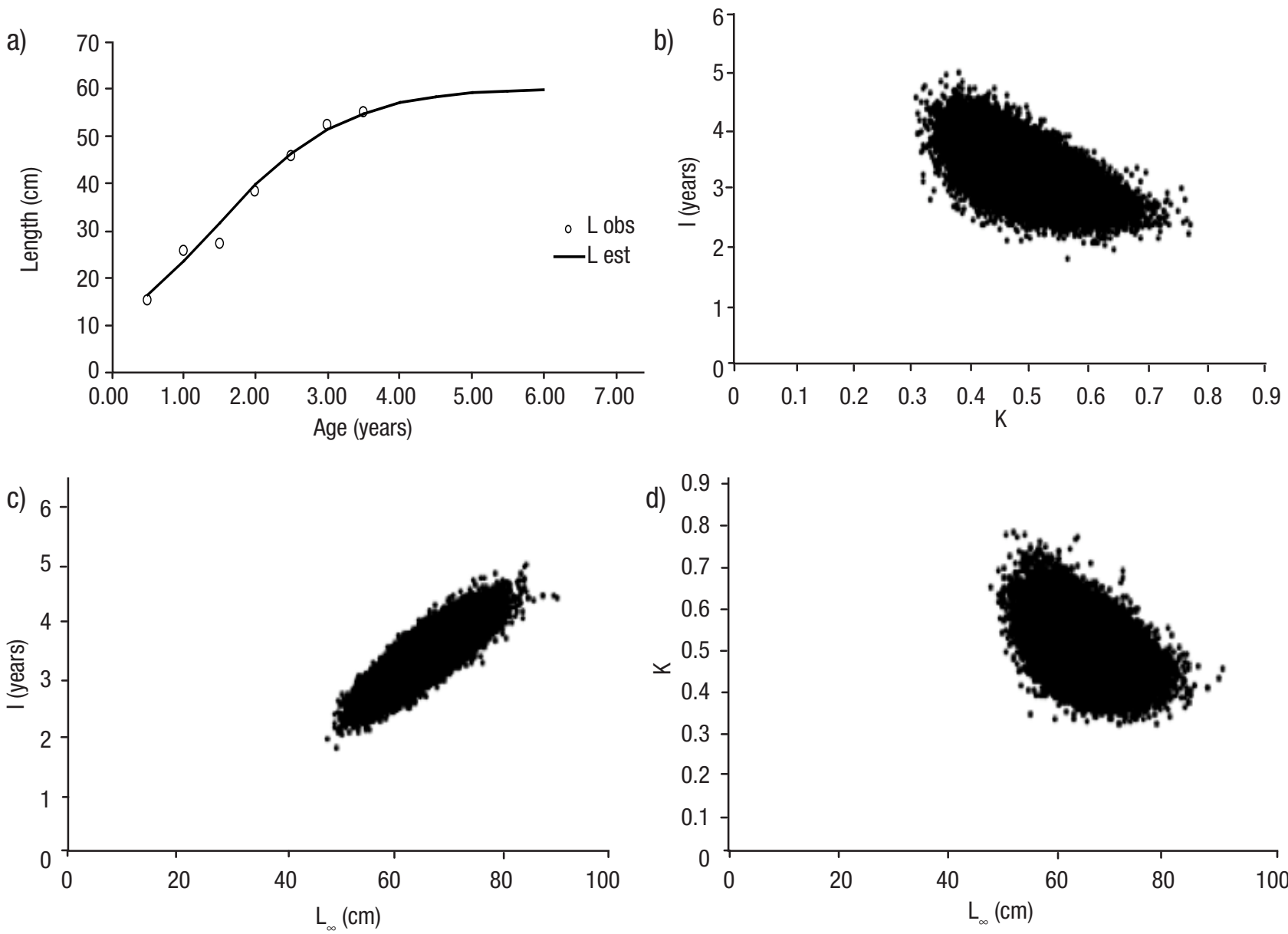

Figures 4a-d. a) Logistic growth model Markov Chain Monte Carlo (MCMC) fitting to observed length data for Yellowtail Snapper (Ocyurus chrysurus Bloch, 1791) in Veracruz; b) Dispersion graph of estimates of $\mathrm{K} v s \mathrm{l}$; c) Dispersion graph of estimates of $\mathrm{L}_{\infty} v s \mathrm{l}$; d) Dispersion graph of estimates of $\mathrm{L}_{\infty}$ vs $\mathrm{K}$. 
the von Bertalanffy model had the worst performance when fitting the observed length-at-age data, surpassed even by the Gompertz model (Gompertz, 1825), so it is important to test several models and apply the AIC when exploring the growth of any species. The Akaike criterion (1973) suggests that von Bertalanffy model was not ideal for describing the growth dynamics of the Yellowtail Snapper in the PNSAV. We recommended using these methodologies for other Yellowtail Snapper distribution areas. We did not include the general Schnute growth model in this analysis because preliminary results suggest that, depending on the initial values for parameters used in the optimization, their estimates converged on all of the three models used.

Not only did the AIC suggest that the von Bertalanffy model does not perform adequately, in particular, asymptotic length estimates from the von Bertalanffy model (Table 3) are high. Based on our experience and conversations with fishermen, there have never been organisms registered of this magnitude. This overestimation may be due to a lack of data from older ages.

The overlap of parameter confidence intervals suggests that all variance error assumptions used in the estimation process produced the same parameter estimates for the logistic model; therefore, it is sufficient to assume that the mean length at age has constant error variance (Equation 5).

Bayesian methods are ideal for including prior knowledge in the estimation of the model parameters, taking advantage of available information. Unfortunately, the lack of studies that integrate model selection methods did not allow building a prior distribution for parameters $\mathrm{I}$ and $\mathrm{K}$; parameters not included in the von Bertalanffy model taken by default in previous studies. We only built a prior distribution for the asymptotic length. The posterior distributions suggest that it does not depend exclusively on the prior distribution; this means that the collected data have enough information to perform the estimation of the asymptotic length parameter. For the asymptotic length, the estimated $L_{\infty}(64.3 \mathrm{~cm})$ obtained with Bayesian analysis is smaller than the one obtained with the maximum likelihood estimation $(64.9 \mathrm{~cm})$. This might be due to the influence that the prior distribution $(\mu=52.86 \mathrm{~cm}, \sigma=$ $9.17 \mathrm{~cm}$ ) has in the estimation process.

Regarding the strong correlation between parameters, there is much statistical confusion among the three parameters of the logistic model, $L_{\infty}, l$, and $K$. Their estimates were based on data from a single season, so there is probably not much contrast in the data. Future sampling will increase the amount of data available for the estimation, would allow better estimates for parameters and uncertainties, and will probably ratify the logistic model as the best for describing YellowtailSnapper growth dynamics.

In this study, we present some statistical techniques that should be considered basic because they provide a robust analysis in assessing the growth of species of commercial interest and are an appropriate solution for estimating the parameters and uncertainty of individual growth. The Bayesian framework presents an opportunity to incorporate historical species information in the management of fishing resources to ensure their sustainable exploitation

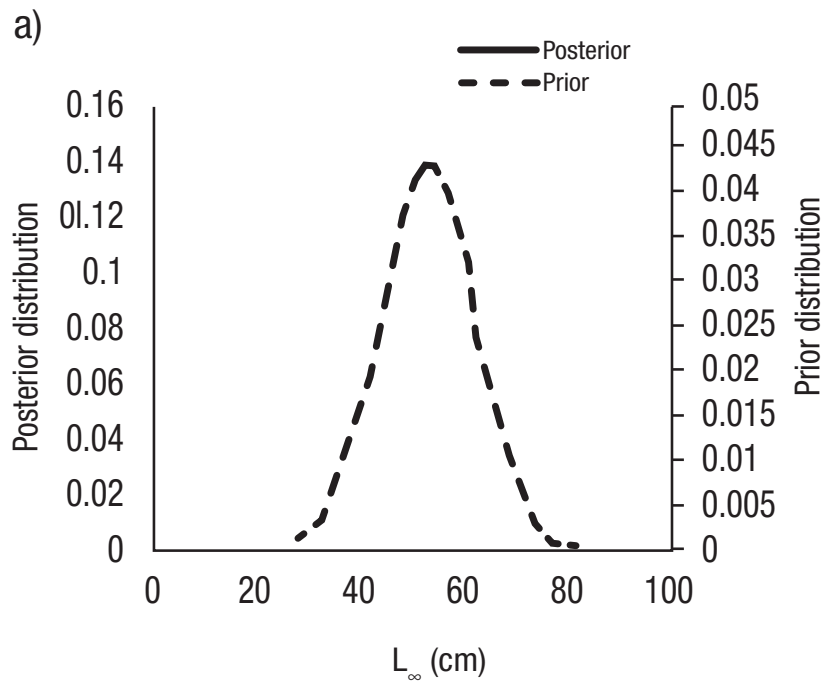

b)

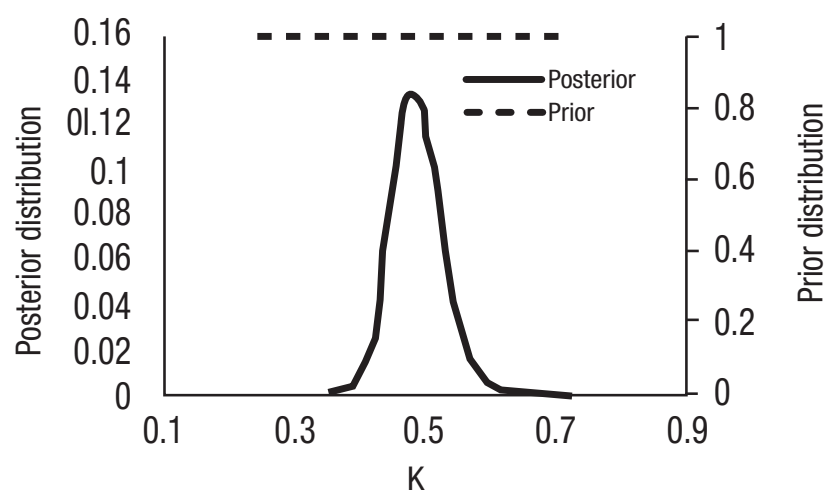

c)

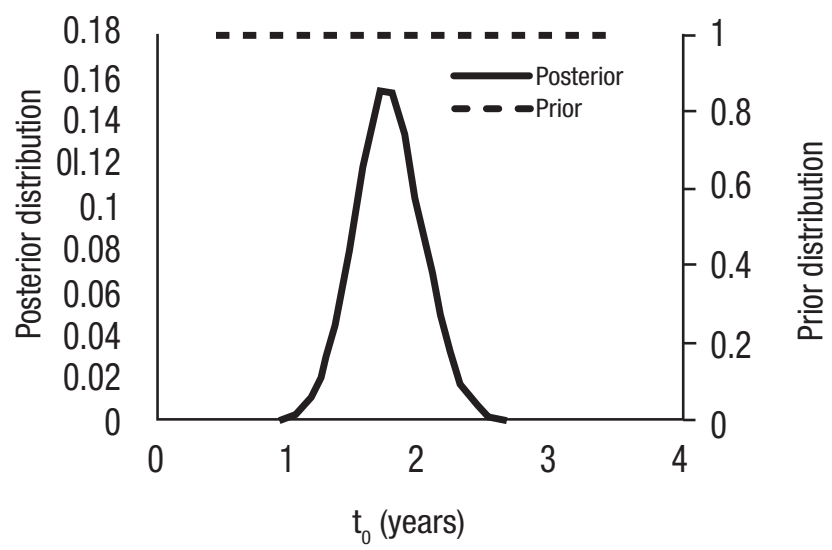

Figures 5a-c. Marginal posterior distributions for the parameters of the logistic growth model. a) Asymptotic length; b) Growth rate; c) Age for the inflexion point. Posterior $=$ posterior distribution; Prior $=$ prior distribution. 
Table 3. Estimated parameters for Yellowtail Snapper Ocyurus chrysurus (Bloch, 1791) and their uncertainty (standard error) for the von Bertalanffy, Logistic and Gompertz models (three error variance assumptions were used: $a=$ equation $4, b=$ equation $5, c=$ equation 6 ); $L_{\infty}=$ asymptotic length; $\mathrm{K}=$ intrinsic rate of growth; $\mathrm{t} / \mathrm{I}=$ time where individual length is cero or the age corresponding to the inflection point in the growth curve (logistic model); $\sigma=$ standard error.

\begin{tabular}{|c|c|c|c|c|c|c|}
\hline Model & $\begin{array}{c}\text { Variance } \\
\text { option }\end{array}$ & $L_{\infty}$ & $\mathrm{K}$ & $\mathrm{t}_{0} / \mathrm{l}$ & $\sigma$ & Akaike \\
\hline \multirow[t]{3}{*}{ Von Bertalanffy } & $\mathrm{a}$ & $166.02 \pm 60.67$ & $0.06 \pm 0.03$ & $-0.28 \pm 0.26$ & $5.72 \pm 0.29$ & 1198.75 \\
\hline & $b$ & $135.63 \pm 77.93$ & $0.07 \pm 0.05$ & $-0.75 \pm 0.49$ & $1.95 \pm 0.52$ & 80.42 \\
\hline & c & $154.77 \pm 84.48$ & $0.07 \pm 0.05$ & $-0.25 \pm 0.42$ & $9.41 \pm 2.55$ & 96.29 \\
\hline \multirow[t]{3}{*}{ Logistic } & a & $66.1 \pm 5.85$ & $0.54 \pm 0.07$ & $3.48 \pm 0.35$ & $5.62 \pm 0.29$ & 1190.34 \\
\hline & $b$ & $64.9 \pm 5.43$ & $0.49 \pm 0.07$ & $3.28 \pm 0.42$ & $1.77 \pm 0.47$ & 31.41 \\
\hline & C & $65.55 \pm 7.2$ & $0.54 \pm 0.09$ & $3.45 \pm 0.43$ & $7.25 \pm 1.94$ & 33.63 \\
\hline \multirow[t]{3}{*}{ Gompertz } & $\mathrm{a}$ & $68.77 \pm 5.81$ & $0.38 \pm 0.05$ & $0.01 \pm 0.54$ & $5.7 \pm 0.29$ & 1193.32 \\
\hline & $b$ & $84.71 \pm 25.76$ & $0.24 \pm 0.09$ & $-3.04 \pm 2.78$ & $1.91 \pm 0.57$ & 36.0 \\
\hline & c & $82.17 \pm 17.88$ & $0.28 \pm 0.08$ & $-1.4 \pm 1.57$ & $8.11 \pm 2,17$ & 34.31 \\
\hline
\end{tabular}

\section{REFERENCES}

Aguirre-García, B., A. Valencia-Cetina, F. Perera-Balan \& A. Medina-Quej. 2004. A preliminary study the fisheries canané (Ocyurus chrysurus) in Holbox, Quintana Roo, Mexico. Resúmenes 55th Gulf and Caribbean Fisheries Institute. p. 2.

AKAIKE, M. 1973. Information theory and an extension of the maximum likelihood principle. In: Petrov, B. \& F. Csaki (Eds.). Proceedings 2nd International Symposium of Information Theory. Akademia Kiado, Budapest, pp. 267-281.

Aldeco, J., A. G. Cortés \& M. J. Jurado-Molina. 2015. Adaptaciones culturales y económicas a cambios provocados por la tala de mangle y deterioro pesquero en Mandinga, Veracruz. Sociedades Rurales, Producción y Medio Ambiente 29 (15): 137-158.

Allen, G. R. 1985. FAO Species Catalogue. Vol. 6 Snappers of the world. An annotated and illustrated catalogue of Lutjanidae species known to date. FAO fisheries synopsis No. 125, Volume 6 . Available online at: http://www.fao.org/docrep/009/ac481e/ac481e00.htm

Allman, R. J., L. R. Barbieri \& C. T. Bartels. 2005. Regional and fisheryspecific patterns of age and growth of yellowtail snapper, Ocyurus chrysurus. Gulf of Mexico Science 23 (2): 211-223.

Araúso, J. N., A. S. Martins \& K. G. Costa. 2002. Idades e crescimento da cioba Ocyurus chrysurus da costa central do Brasil. Revista Brasileira de Oceanografía 50: 47-57.

Borton, S. A. \& J. L. Willıams. 1986. Species profile: life histories and environmental requirements of coastal fishes and invertebrates (South Florida) gray, line, mutton, and yellowtail snappers. U.S. Fish and Wildlife Service Biological Report 82: 1-18.

Briggs, A. H., M. C. Weintein, F. E. A. Lenwick, J. Karnon, M. J. Sculpher \& A. D. PALTIEL. 2012. Model parameter estimation and uncertainty: A report of the ISPOR-SMDM modeling good research practices task force-6. Value in Health 15: 835-842.
Carrillo de Albornoz, C. \& M. Ramiro. 1988. Estudio biológico de la rabirrubia Ocyurus chrysurus en el oeste de la plataforma suroriental de Cuba. I. Edad y crecimiento. Revista de Investigaciones Marinas 1 (9): 9-24.

Carrillo de Albornoz, C. 1999. Crecimiento y evaluación de la rabirrubia (Lutjanus chrysurus) en el oeste de la plataforma suroriental de Cuba. Revista de Investigaciones Marinas 20 (1-3): 45-52.

DenNIS, G. D. 1991. The validity of length-frequency derived growth parameters from commercial catch data and their application to stock assessment of the yellowtail snapper (Ocyurus chrysurus). Proceedings of the Gulf and Caribbean Fisheries Institute 40: 126-138.

EhrHaRdt, N. M. 1981. Curso sobre métodos de evaluación de recursos y dinámica de poblaciones. 3ra. parte. Parámetros poblacionales. FA0-CICIMAR. La Paz, BCS, México. 134 p.

Garcia, E. R., J. C. Potts, R. A. Rulffson \& C. S. Manooch. 2003. Age and growth of yellowtail snapper, Ocyurus chrysurus, from the southeastern United States. Bulletin of Marine Science 72 (3): 909-921.

GomperTz, B. 1825. On the nature of function expressive of the law of human mortality and on a new mode of determining the value of life contingences. Philosophical. Transactions of the Royal Society of London 115: 515-585.

Gutiérrez-Benitez, 0. 2012. Aspectos biológico pesqueros de la rubia Ocyurus chrysurus (Bloch, 1791) en Antón Lizardo, Veracruz, México. Tesis de Maestría. Universidad Veracruzana, Veracruz, México. 58 p.

Heemstra, P. C. \& J. E. Randall. 1993. FA0 species catalogue. Vol. 16 Groupers of the world (Family Serranidae, Subfamily Epinephelinae). An annotated and illustrated catalogue of the grouper, rockcod, hind, coral grouper and lyretail species known to date. FAO Fisheries Synopsis 16 (125), 382 p., 522 figs, 31 colour plates. Available online at: http://www.fao.org/docrep/009/t0540e/ t0540e00.HTM 
Hilborn, R. \& M. Mangel. 1997. The ecological detective: Confronting Models with Data. Princeton University Press, Princeton, New Jersey, $315 \mathrm{p}$.

INAPESCA (Instituto Nacional de PeScA). 2012. Carta Nacional Pesquera. Diario Oficial de la Federación, 24 de agosto de 2012.

Jiménez-Badillo, M. L., H. Pérez, J. M. Vargas, J. C. Cortés \& P. Flores. 2006. Catálogo de especies y artes de pesca del Parque Nacional Sistema Arrecifal Veracruzano. 1er. Ed., Comisión Nacional para la Biodiversidad (CONABIO). Universidad Veracruzana, Boca del Río, Veracruz, 182 p.

Jiménez-Badillo, M. L., \& L. G. Castro-Gaspar. 2008. Pesca artesanal en el Parque Nacional Sistema Arrecifal Veracruzano, México. In: Granados-Barba, A., L. Abarca-Arenas \& J. M. Vargas-Hernández (Eds.). Investigaciones Científicas en el Sistema Arrecifal Veracruzano. Universidad Autónoma de Campeche, Campeche, pp. 221-240.

JoHnson, A. G. 1983. Age and growth de yellowtail snapper from south Florida. Transactions of American Fisheries Society 112: 173-177. DOI:10.1577/1548-8659(1983)112<173:AAGOYS>2.0.C0;2

Karnon, M. J. Sculpher \& A. D. Paltiel. 2012. Model parameter estimation and uncertainty: A report of the ISPOR-SMDM modeling good research practices task force-6. Value in Health 15: 835-842. DOI:10.1016/j.jval.2012.04.014

KImURA, D. K. 1980. Likelihood methods for the von Bertalanffy growth curve. Fisheries Bulletin 77: 765-774.

Leite JR, N. 0., A. S. Martins \& J. N. Araújo. 2005. Idade e crescimento de peixes recifais na regiao central da zona económica exclusiva entre Salvador-BA e o Cabo de Sáo Tomé-RJ. (13ㅇ a $\left.22^{\circ} \mathrm{S}\right)$. In: Costa, P. A. S., A. S. Martins \& G. Olavo (Eds.). Pesca e potenciais de exploracao de recursos vivos na regiao central da zona económica exclusiva brasileira. Rio de Janeiro, Brasil, pp. 203-216.

Manooch III, C. S. \& C. Drennon. 1987. Age and growth of yellow snapper and queen triggerfish collected from the U.S Virgin Islands and Puerto Rico. Fisheries Research 6: 53-68. D0I:10.1016/01657836(87)90006-3

Mattos, S. G. M. \& F. Maynou. 2009. Virtual population analysis of two snapper species, Lutjanus analis and Lutjanus chrysurus, caught off Pernambuco state, north eastern Brazil. Brazilean Journal of Oceanography 57 (3): 229-242. D0I:10.1590/S1679-87592009000300006
Maunder, M. N., S. J. Harley \& J. Hampton. 2006. Including parameter uncertainty in forward projections of computationally intensive statistical population dynamics. ICES Journal of Marine Sciences 63: 969-979. D0I:10.1016/j.icesjms.2006.03.016

McClellan, D. B. \& N. J. Cummings. 1998. Fishery and biology of the yellowtail snapper, Ocyurus chrysurus, from the southeastern United States, 1962 through 1996. Proceedings of the Gulf and Caribbean Fisheries Institute 50: 827-850.

Mexicano-Cíntora, G. 1999. Crecimiento del pargo canané Ocyurus chrysurus de la costa norte de Yucatán, México. Proceedings of the Gulf and Caribbean Fisheries Institute 45: 338-348.

OKoLodkov, Y. B. 2008. Protoperidinium Bergh (Dinophyceae) of the National Park Sistema Arrecifal Veracruzano, Gulf of Mexico, with a key for identification. Acta Botanica Mexicana 84: 93-149.

Punt, A. E. \& R. HILBorn. 2001. BAYES-SA: Bayesian Stock Assessment Methods in Fisheries. User's manual. FAO Computerized Information Series (Fisheries) No. 12, Rome, 56 p.

R Core TeAm. 2015. R: A language and environment for statistical computing. R Foundation for Statistical Computing, Vienna, Austria. Available on line at: http://www.R-project.org/

RICKER, W. E. 1975. Computation and interpretation of biological statistics of fish populations. Bulletin of Fisheries Research Board of Canada 191: 1-382.

Riley, C. M., G. J. Holt \& C. R. Arnold. 1995. Growth and morphology of larval and juvenile captive bred yellowtail snapper, Ocyurus chrysurus. Fisheries Bulletin 93 (1): 179-185.

SAGARPA (Secretaría de Agricultura, Ganadería, Desarrollo Rural, Pesca y Alimentación). 2012. Carta Nacional Pesquera. Diario Oficial de la Federación, 24 de agosto de 2012.

Sedar III (Southeast Data, Assessment and Review). 2003. A stock assessment of yellowtail snapper, Ocyurus chrysurus, in the Southeast United States. Final report to the National Marine Fisheries Service, the Gulf of Mexico Fishery Management Council, and the South Atlantic Fishery Management Council. St. Petersburg, FL., 216 p.

Torres, R. \& E. A. Chávez, 1987. Evaluación y diagnóstico de la pesquería de rubia (Lutjanus synagris (L) en el Estado de Yucatán. Ciencias Marinas 13 (1): 7-29.

Von BertalanfFy, L. 1938. A quantitative theory of organic growth (Inquiries on growth laws II). Human biology 10 (2): 181-213. 